28. On Cryptostome Beetles in the Cambridge University Museum of Zoology. By S. Maulik, B.A. (Cantab.), F.E.S., Imperial College of Science and Technology, London*.

[Received May 22, 1916 : Read October 24, 1916.]

(Text-figures $1 \& 2$.)

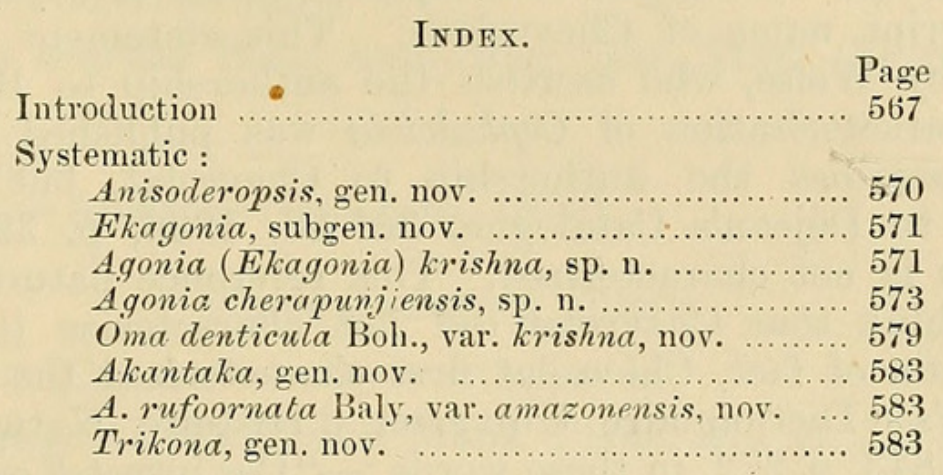

The present paper is based on the collection of Hispinæ and Cassidinæ contained in the Museum of Cambridge University. The collection is a representative one, in that it is composed of species from all parts of the world. There are 271 specimens representing 14 genera and about 40 species of Hispinæe and 34 genera and about 68 species of Cassidinæ. Owing either to the imperfect condition of the specimens or to insufficiency of material, I have been able to deal with only 47 genera ajd 80 species of both groups in this paper.

I have studied this collection in conjunction with similar material in the British Museum (Nat. Hist.). This method has afforded me the opportunity of examining a large number of examples, with the result that I have been able to study critically some of Boheman's genera and to propose some alterations. I have also been able to supply information on certain points which are left as doubtful in Spaeth's recent 'Catalogue of Cassidinæ.' In a few cases the priority of the names of certain genera has been discussed. Three new genera, one new subgenus, and two new species are now proposed here. In the following list of determinations wherever the range of a species is not indicated it has been reported only from the locality which is mentioned in this paper.

I wish to express my indebtedness to Dr. C. J. Gahan, who has always kindly given me the benefit of his opinion on many points. My thanks are also due to Mr. Scott, of the Cambridge Museum, whose assistance at the initial stage of the study I wish to acknowledge. This piece of work was done while I was a student of the Imperial College of Science. I take this opportunity of expressing my thanks to Profs. MacBride and Lefroy, of the zoological department of the College.

\footnotetext{
* Communicated by the Secretary.
} 


\section{AMERICAN HISPIN A.}

Genus Cephaloleia Chevrolat.

Chevrolat, Charles d'Orbigny's Dict. Universal d'Hist. Naturelle, iii. 1843 , p. 272 ; Blanchard, Hist. Ins. ii. 1845 , p. 182 ; Baly, Cat. Hisp. 1858 , p. 39, t. 1. f. 12 ; Chapuis, Gen. Col. xi. 1875, p. 277 ; Weise, Arch. f. Naturg. 1910, p. 82.

Baly, in his 'Catalogue of Hispidæ,' refers to Cephaloleia as a manuscript name of Chevrolat's. This statement has been accepted by Weise, who ascribes the authorship to Blanchard, whose characterization of Cephaloleia was published in 1845 . Chapuis ascribes the authorship to Chevrolat, but gives a reference to Dejean's Catalogue, 3rd ed. 1836, p. 390, where the genus is not characterized. This reference naturally leads one to think that Chevrolat did not characterize the genus. As a matter of fact, Chevrolat first characterized the genus in d'Orbigny's 'Dictionnaire Universel d'Histoire Naturelle,' iii. January 1843 , p. 272 , in these words:- "Ces insectes ont un peu du facies des Cassidaires, mais ils sont étroits, quelquefois allongés carrément, entièrement lisses, sans épines; leur corselet est ou arrondi en avant et sur les côtés, ou en carré transverse. Les Hispa metallica, nigricornis, Fabr., l'Hisp. nigricornis d'Olivier, espèce distincte de la première, et l'Alumus cyanipennis de Perty rentrent dans ce genre." This description is signed C. There are various dates on the title-pages of d'Orbigny's 'Dictionnaire.' The question of these dates has been gone into by Sherborn and Palmer (Ann. Mag. N. H. (7) iii. April 1899, pp. 350-2). According to them the third volume of d'Orbigny's 'Dictionnaire,' in which the description of Cephaloleia occurs, was first published as a completed volume in January 1843. I have consulted the copy belonging to the Zoological Society of London, the title-page of which bears the same date.

Weise has changed the spelling of the name of the genus by omitting the "e" between the "l" and "i." I prefer to adhere to Chevrolat's original spelling, because this custom of latinising the names has led to great confusion in many cases.

\section{Cephaloleia nigricóoris Fab.}

Cephaloleia nigricornis Fabricius, Ent. Syst. i. 1792, pt. 2, p. 73 ; Olivier. Encycl. Méth. vii. 1792, p. 99, Ent. vi. 1808, p. 773, t. 2. f. 25 ; Baly, Cat. Hisp. 1858, p. 47.

3 examples.

Localisy.-Amazons (Goodman, 1879).

Cephaloleia proxima Baly.

Cephaloleia proxima Baly, Cat. Hisp. 1858, p. 47.

1 example.

Locality.-Amazons (Goodman, 1879).

Baly reports it from Cayenne, Guiana. 
Cephaloleia eximia Baly.

Cephaloleia eximia Baly, Cat. Hisp. 1858, p. 53.

2 examples.

Locality.-Amazons (Goodman, 1879).

Baly reports it from Cayenne, Guiana.

Genus Stethispa Baly.

Stethispa confusa Baly.

Stethispa confusa Baly, Ann. Mag. Nat. Hist. (3) xiv. 1864, p. 267.

1 example.

Locality.-Amazons (Goodman, 1879).

Genus Chalepus Thunb.

Chalepus (Chalepus) sanguinicollis L.

Hispa sanguinicollis Linné, Mant. Plant. Alt. vi. 1771, p. 530. 2 examples.

Locality.-Amazons (Goodman, 1879).

Range. Middle and South America.

\section{OLD WORLD HISPIN $A$.}

Genus Botryonopa Blanch.

Botryonopa speCtabiLIS Baly.

Botryonopa spectabilis Baly, Cat. Hisp. 1858, p. 93 ; Gestro, Ann. Mus. Stor. Nat. Genova, 1897, p. 44.

2 examples.

Locality.--Malay Penin. (Skeat Expedition, 30. xi. 1899).

Range. Malacca, Sumatra.

Botryonopa grandis Baly.

Hispopria grandis Baly, Cat. Hisp. 1858, p. 95.

1 example.

Loeality._Borneo (Shelford).

Range. Sumatra, Java.

Genus Anisodera Chevrolat.

Chevrolat, C. d'Orbigny's Dict. Univ. d'Hist. Nat. i. 1847, p. 535 ; Baly, Cat. Hisp. 1858, p. 101, t. 2. f. 8 ; Chapuis, Gen. Col. xi. 1875, p. 295 ; Weise, Deut. Ent. Zeit. 1897, p. 118.

The authorship of this genus must be attributed to Chevrolat and not to Baly, as has hitherto been done. It was an oversight on Baly's part to call Anisodera a manuscript name. In Charles d'Orbigny's 'Dictionnaire,' i. p. 535, Anisodera is described as follows:- “Genre de Coléoptères tétramères, famille des Chrysomélines, tribu des Hispoides, établi par M. Chevrolat aux dépens

Ṕroc. Zool. Soc.-1916, No. XL. 
du g. Aiurnus de Fabricius, et adopté par M. Dejean (Cat. $3^{\text {e }}$ edit.), qui y rapporte deux esp. de Java, savoir : l'A.lucidiventris Buquet, et l'A. ferruginea, qui est l'Alurnus ferrugineus de Fabr.-Les caract. de ce g., d'après M. Chevrolat, sont: Tête avancée, arrondie, entaillée circulairement sur la face. Palpes assez développés: le dernier article des maxillaires long, un peu renflé au milieu. Antennes presque réunies par la base sur le front, épaisses, cylindroïdes, de 11 articles : les cinq $1^{\text {ers }}$ lisses ; les $3^{\text {e }}$ et $4^{\text {e }}$ du double plus longs que le $2^{\text {e }}$; les suivants presque égaux, un peu plus allongés; le dernier terminé en pointe mousse. Corselet plus long que large, inégal, coupé obliquement en avant, droit à la base, conné et abaissé sur les côtés. Elytres modérément convexes, à stries ponctuées, arrondies à l'extrémité et non armées. Pattes simples, trapues; les $2^{\text {e }}$ et $3^{\text {e }}$ articles des tarses profondément bilobés."

I have quoted this in full from the copy of the first volume of the 'Dictionnaire' belonging to the Zoological Society of London, which bears the date 1847 on the title-page (the first volume was, however, first published in 1841 - see Sherborn \& Palmer, "Dates of Charles d'Orbigny's Dictionnaire Universal d'Histore Naturelle, 1839-1849," Ann. Mag. N. H. (7) iii. 1899, pp. 350-2), because there was a re-composition of the matter of the first volume at a later date.

From the above, it will be seen that Alurnus ferrugineus F. and A. lucidiventris Guérin were separated from the genus Alurnus and formed into a new genus which Chevrolat called Anisodera. As one of those species must be taken as the type of the genus Anisodera, I select Fabricius's species ferrugineus as being earlier than Guérin's. But both ferrugineus and lucidiventris are now included in a subgenus Lissochila, while Anisodera excavata Baly is made the type of Anisodera proper. There exist good structural differences between the subgenera which are fairly constant, and I consider them to be of generic importance. Owing to this fact and in view of the present note on the priority of Chevrolat's description of Anisodera, I propose to erect a new genus and sink Lissochila as a synonym of Anisodera as follows :-

i. Labrum short, the transverse edge emarginate and covered with long and stiff hairs. The labrum lies in a lower plane than the clypeus. Upper side of the body shining. Elytra without pronounced ribs. ...... Anisoderopsis, gen. n.

(Type A. excavata Baly.)

ii. Labrum large, the transverse edge straight, sparsely covered with hairs. Labrum lies in the same plane as the clypeus, which is small and almost plain. Upper side of the body, as a rule, opaque. Elytra with pronounced ribs.

(Type A. fermginea Fab.)

Anisodera Chevrolat. 


\section{Genus Onchocephala Chevr.}

ONCHOcEPHALA QUADRILOBata Guérin.

Onchocephala quadrilobata Guérin, Icon. Règn. Anim., Ins. 1844, p. 281 ; Weise, Deut. Ent. Zeit. 1897, p. 121 and 1905, p. 117; Gestro, Ann. Mus. Stor. Nat. Genova, 1899, p. 314, f. 1 ; Maulik, Rec. Ind. Mus. Caleutta, 1915, p. 372.

1 example.

Locality.-Ceylon, Oct. (Fryer).

Range. India, Andaman Islands.

\section{Genus Agonia Weise.}

The genus Agonia is divided into two subgenera according to the number of costæ on each elytron, thus :-Elytra with three costæ and eight or more rows of punctures, Agonia s. str.; elytra with two costæ and six rows of panctures, Agonella Weise. In the present case there are four costæ and ten rows of punctures, I therefore take the following new species (Agonia krishna) as the type of a new subgenus which I name Elagonia. The convexity of the eyes, the low costæ, the smooth parallel rows of punctures, the form of the body, all point to the conclusion that Agonia krishna has close affinity to the genus Downisia Baly. The species included in the subgenus Agonella have higher costæ, coarser punctures, and the body more dilated behind-characters which are strongly marked in the next genus Gonophora. For these reasons I place Agonia krishna at the beginning of the genus Agonia.

\section{EKAGONIA, subgen, nov.}

Agonia (Ekagonia) krishna, sp, n. (Text-fig; 1.)

Elongate, parallel-sided, black, shining. First two joints of antennæ shining, the rest of the joints pubescent; interantennal space with a protuberance; eyes strongly convex. Prothorax parallel-sided, base bisinuate, moderately convex, disc shining, with a few scattered deep punctures, anterior surface transversely strigose with a few brownish hairs, base with a deep triangular fossa, each side with two shallower and rounded fossæ or depressions. Scutellum smooth, shining, with the apex rounded. Elytra with four costæ, first costa slightly elevated, ten rows of punctures, between the suture and the first costa only one row of punctures.

Length, from head to apex of elytra, $5.5 \mathrm{~mm}$.

Described from one example.

Locality.-Borneo (Shelford).

Type in the British Museum.

Head. The bases of the antennæ are well separated from the mouth-parts by the clypeus, which is strigose and depressed in the middle. Labrum covered with brownish hairs. Seen from above, the interantennal process is so prominent that it conceals 
the bases of the antennæ from view. Antennæ, first two joints shining and rounded, third joint longest, after the third joint the antennæ are gradually thickened towards the apex. Prothorax cylindrical, sides with bisinuate margins ; front margin straight, brownish; posterior to the front margin the surface is transversely strigose and is sparsely covered with fine brownish hairs. Disc smooth, shining, with a few deep punctures. At the base in the middle is a very deep triangular fossa. On each side of the disc two depressions, the anterior shallower than the posterior; concavity of the depressions with deep punctures. Scutellum small, oval, smooth, shining. In this specimen there are about four small punctures near the margins. Elytra parallel sided, with four costæ on each elytron. The first costa is slightly

Text-figure 1.

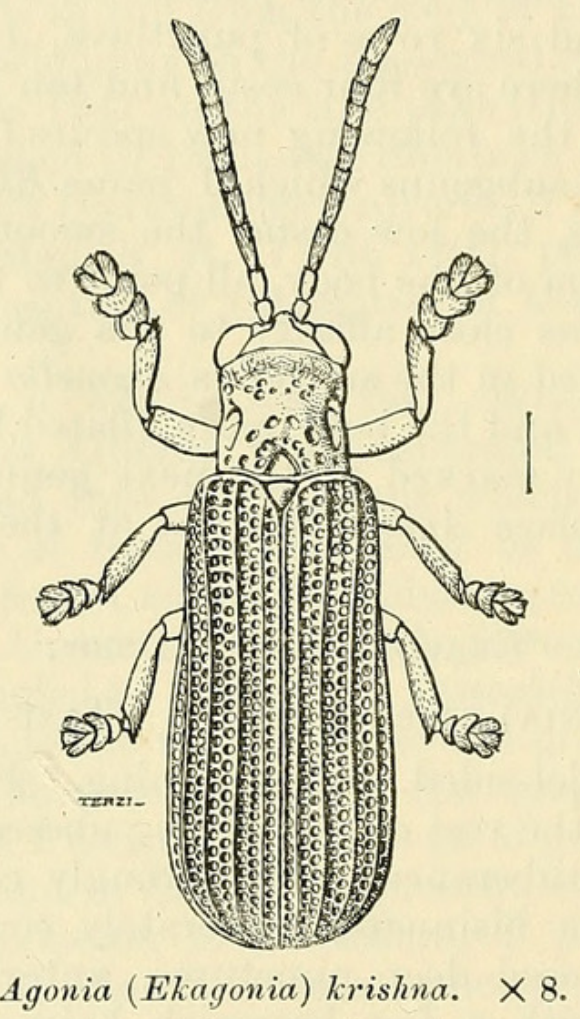

elevated, the suture is as much elevated as the first costa if not more. The second costa is more elevated than the first, the third and fourth prominently elevated. All the costæ meet at the apex of the elytra. On each elytron there are altogether ten parallel rows of punctures disposed as follows:-Between the suture and first costa one row; between first and second costæ two rows; between second and third costæ two rows; between third and fourth costæ two rows; between fourth and lateral margin three rows. Underside smooth, shining, sparsely covered with brownish hairs; mentum, coxæ, margins of the abdominal sternites, tibiæ and tarsi with brownish tinge; fourth joint of tarsus not longer than the third, claws more or less hidden in the thick pubescence of the underside of the tarsus. 
Agonia cherapunjiensis, sp. n. (Text-fig. 2.)

Elongate. Upperside subnitid, underside shining. Head, antennæ, underside, legs, a longitudinal middle line on the pronotum and the scutellum black, elytra and the rest of the body fulvous. Three costre on each elytron. Three rows of punctures between the suture and the first costa.

Length, from head to the apex of elytra, $14.5 \mathrm{~mm}$.; antenna, $6 \mathrm{~mm}$.; pronotum, $3 \mathrm{~mm}$.

Locality.-Cherapunji, Assam, N.E. India (taken by Mrs. Somerset, 15. vii. 1907).

Described from one example.

Type in the British Museum.

Text-figure 2.

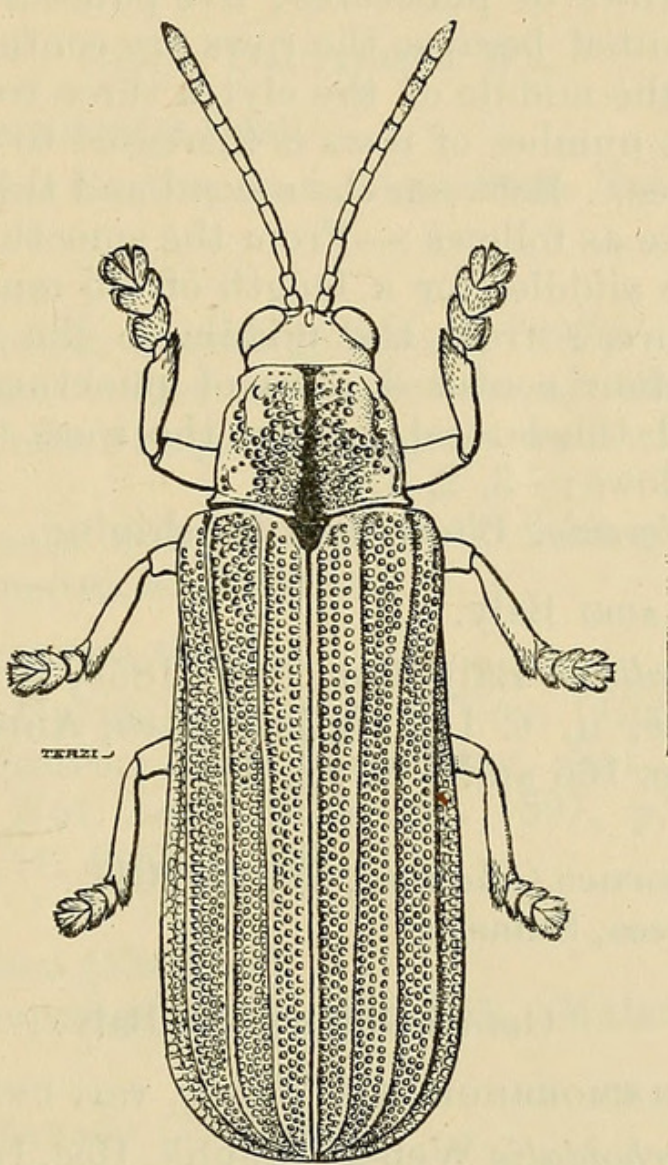

Agonia cherapunjiensis. $\times 4$.

Head. Antennæ moderately stout, basal joint short, second joint constricted at base, third joint longest, fourth joint shorter than third but longer than each of the following joints, fifth to seventh subequal, eighth to tenth equal but shorter than each of the preceding joints, eleventh joint bluntly pointed ; surface of all the joints except the third hairy and with elongate punctures. Clypeus much broader than long, apex produced into a process which passes beyond the interantennal space. Labrum rufescent, edges bristly. Mandibles broad, black, very 
powerful. Maxillary palpi 4-jointed, fulvous, hairy, fourth joint darker in colour and bluntly pointed. Labial palpi 3-jointed, fulvous, hairy, apex of second and third joints black, second joint dilated at the apex. Prothorax almost as long as broad, sides with a margin, a longitudinal broad black shining impunctate raised line in the middle, on each side of this line a raised impunctate surface. The surface of the pronotum is coarsely and broadly punctate, punctures becoming smaller near the base. Scutellum broader at base, apex rounded, black, impunctate. Elytra: length $11.5 \mathrm{~mm}$.; slightly broadened at apex. Fulvous. Tricostate and punctate-striate. Between the suture and the first costa three rows of punctures throughout the whole length of the elytra; between the first and second costre the rows of punctures vary; for a length of $2.5 \mathrm{~mm}$. just beyond the base there are four rows of punctures; five punctures in a transverse line can be counted because the rows are confused; for a length of $2.5 \mathrm{~mm}$. in the middle of the elytra three rows of punctures; beyond this the number of rows is increased to four; at the apex it is again three. Between the second and third costre the rows of punctures are as follows :- From the smooth shining humeral callus up to the middle (for a length of $4.5 \mathrm{~mm}$.) two and three rows of punctures; from the middle to the apex (except the extreme apex) four confused rows of punctures. Between the third costa and the lateral margin the rows of punctures may be stated as follows: $-3,2,3,4,3$.

Legs and underside. Black, smooth, shining.

Agonia wallacei Baly.

Gonophora wallacei Baly, Cat. Hisp. 1858, p. 109; Waterhouse, Aid. Ident. Ins. ii. t. 153. f. 7 ; Gestro, Ann. Mus. Stor. Nat. Genova, 1885, p. 165 and 1897, p. 55.

3 examples.

Locality.-Borneo (Shelford, 20.x. 1901).

Range. Malacca, Sumatra.

\section{Genus Gonophora Baly.}

Gonophora HæMorrhoidalis Weber, var. undulata Weise.

Hispa homorrhoidalis Weber; Maulik, Rec. Ind. Mus. Calcutta, xi. 1915 , p. 373.

4 examples.

Locality.-Borneo (Shelford ).

Range. India and the Indo-Malay Penin. Region.

Gonophora chalybeata Baly.

Gonophora chalybeata Baly, Cat. Hisp. 1858, p. 115 ; Gestro, Ann. Mus. Stor. Nat. Genova, 1885, p. 168 ; Bull. Soc. Ital. 1902 (1903), p. 146.

1 example.

Locality.-Borneo (Shelford).

It has also been reported from Singapore. 
GoNophora (LACHNisPa) MODIGLIANiI Gestro.

Gonophora (Lachnispa) modiglianii Gest. Ann. Mus. Stor. Nat. Genova, 1892, p. 793 and 1897, p. 65.

1 example.

Locality.-Borneo (Shelforl).

Dr. Modigliani first took this species at Egano Island.

Genus Hispella Chap.

Hispella atra Linné.

Hispella atra L.; Maulik, Rec. Ind. Mus. Calcutta, xi. 1915, p. 375 .

1 example.

Locality.-Palestine (Tristram).

Range. Europe, North Africa, Asia Minor, Turkistan.

Genus Dactylispa Ws.

Dactilispa longicuspis Gest.

Hispa longicuspis Gestro, Ann. Mus. Stor. Nat. Genova, 1897, p. 108, fig.

1 example.

Locality.-Sarawak, Borneo (Shelford, 1897).

In the specimen before me the base of the elytra is not ferruginous. In other respects it agrees well with Dr. Gestro's description.

This species has a wide distribution, having been reported from Malacca, Sumatra, and Borneo.

Dactylispa Bipartita Guérin.

Hispa bipartita Guérin in Duperrey Voy. 'Coquille,' Zool. ii. 1830, p. 141 ; Gestro, Ann. Mus. Stor. Nat. Genova, 1897, p. 109, fig.; and Not. Leyd. Mus. xix. 1897, p. 175 ; Ritsema, Midden-Sumatra, iv. 1887, p. 180.

2 examples.

Locality.-Borneo (Shelford).

It has been reported from Sumatra, Malacca, Java, and Borneo.

DaCtylispa malayana (?) Gestro.

Dactylispa malayana Gestro, Bull. Soc. Ent. Ital. 1909 (1910), p. 139 .

1 example.

Locality.-Malay Penin. (Skeat Expedition, 20. xi. 1900).

The species is identified from description.

Dactylispa Fulvipes (?) Motsch.

Hispa fulvipes Motschulsky, Schrenck's Reise Amur. ii. 1861, p. 238 ; Gestro, Bull. Soc. Ent. Ital. 1902, p. 56.

1 example.

Locality.-Ceylon (Fryer).

The species is identified fiom description. 


\section{DACTYLISPa TRIFIDa (?) Chap.}

Hispida trifida (?) Chapuis, Ann. Soc. Ent. Belg. xx. 1877, p. 55; Gestro, Ann. Mus. Stor. Nat. Genova, 1885, p. 176 and 1897, p. 92.

1 example.

Locality.-Sarawak (Shelford, 1897).

This species has also a very wide distribution, laving been reported from Malacca, Sumatra, and Java. The species is identified from description.

DaCTYLISPA SOROR Weise.

Dactylispa soror Weise, Deut. Ent. Zeit. 1897, p. 134 and 1905, p. 120. examples.

Locality.-Peradeniya, Ceylon (Fryer).

The occurrence of this species in Ceylon is recorded here for the first time. The other locality where it has been taken is the Nilgiri Hills.

Dactylispa spinosa (?) Weber.

Hispa spinosa Weber; Maulik, Rec. Ind. Mus. Calcutta, xi. 1915 , p. 379.

1 example.

Locality.-Borneo (Shelford).

Range. Sumatra, Celebes.

The species is identified from description.

Dactylispa leptacantha Gestro.

Hispa leptacantha Gestro, Ann. Hus. Stor. Nat. Genova, 1897, p. 98; and Bull. Soc. Ent. Ital. 1904 (1905), p. 151.

5 examples.

Locality. -Sarawak (Shelford, 1897).

Range. Malacca, Sumatra, Borneo.

\section{Genus Hispa L.}

HisPa FabRiciI Guér.

Hispa fabricii Guérin in Duperrey Voy. 'Coquille,' Zool. ii. 1830, p. 140 ; and Icon. Règn. Anim., Ins. 1844, p. 268, t. 48. f. 3 ; Gestro, Ann. Mus. Stor. Nat. Genova, 1885, p. 174.

1 example.

Locality.-New Britain (Willey, 1. iii. 1898).

Range. New Guinea, New Pomerania, New Mecklenburg.

\section{Genus Platypria Guér.}

Platypria echidna Guér.

Plabypicia echidnca Guérin, Rev. Zool. 1840, p. 139; Gestro, 
Ann. Mus. Stor. Nat. Genova, 1890, p. 246, fig., and 1897, p. 112 ; Maulik, Rec. Ind. Mus. Calcutta, xi. 1915 , p. 380.

1 example.

Locality.-Peradeniya, Ceylon (Fryer).

Range. India, Ceylon, Tonkin.

Platypria hystrix F.

Hispa hystrix Fabricius, Suppl. Ent. Syst. 1798, p. 116 ; Maulik, Rec. Ind. Mus. Calcutta, xi. 1915, p. 381.

1 example.

Locality.-Peradeniya, Ceylon (Fryer).

Range. India, Ceylon.

\section{CASSIDIN $A$.}

\section{Genus Himatidium F.}

Himatidium capense Herbst.

Cassida capensis Herbst, Natursyst. Käf. viii. 1799, p. 278, t. 133 . f. 10 .

Himatidium comptum Perty, Delect. Anim. Bras. 1830-34, p. 101, t. 20. f. 8; Guérin, Icon. Règn. Anim., Ins. 1844, p. 286.

Imatidium fasciatum Fabricius, Syst. El. i. 1801, p. 346 ; Illiger, Mag. Ins. i. 1802, p. 392.

Cassida fasciata Olivier, Ent. vi. 1808, p. 971 ; 97, t. 6.

f. 100 .

Himatidium fasciatum Boheman, Mon. Cassid. i. 1850, p. 65, t. 2. f. 13 .

4 examples.

Locality.-A mazons (Gogdman, 1879).

Range. Brazil, Bolivia, Ecuador, Peru.

\section{Genus Prioptera Hope.}

Prioptera westermanni Mannh.

Priopterc westermanni Mannerheim, Bull. Soc. Nat. Mosc. xvii. 1844 , p. 864 ; Boheman, Mon. Cassid. i. 1850 , p. 45.

1 example.

Locality.-Shan States, Burma, 23. iii. 1905.

Range. Assam, Tenasserim, Tonkin.

Prioptera octopunctata F.

Cassida octopunctata Fabricius, Mant. Ins. 1787, p. 63 ; Ent. Syst. i. 1792 , p. 296 ; Syst. El. i. 1801, p. 395; Linné, Syst. Nat. ed. xiii, Gmel. 1787, i., iv. p. 1636 ; Olivier, Enc. méth. v. 1790, p. 382 , and Ent. vi. 1808 , p. 946 ; 97, t. 3. f. 38 ; Herbst, Natursyst. Käf. viii, 1799 , p. 334 . 
Prioptera octopunctata Boheman, Mon. Cassid. i. 1850, p. 55.

Prioptera decempustulata, Boh. Mon. Cassid. i. 1850, p. 55.

Boheman distinguishes decempustulata from octopunctata thus:- "Statura et summa similitudo P. 8-punctatce, sæpe nonnihil major, antennis totis flavo-testaceis, elytris subtiliter, vage punctulatis, pectore nigro, ab illa bene distincta." I have examined thirty-eight examples of decempustulata and octopunctata (Brit. Mus. Coll. \& Camb. Univ. Coll.). In view of the material before me, I am in a position to state that the characters mentioned by Boheman to distinguish 10-pustulata from 8-punctata are untenable. These characters are merely individual variations. Moreover, the genus Prioptera is well known for the variability of its species. I therefore regard 10-pustulata as a synonym of 8-punctata $\mathrm{F}$.

13 examples.

Locality.-Borneo (Shelford).

Range. Malacca, Sumatra, Java, Siam.

\section{Genus Epistictia Boh.}

Epistictia matronula Boh.

Epistictia matronula Boheman, Mon. Cassid. i. 1850, p. 14 ; Weise, Deut. Ent. Zeit. 1901, p. 49.

1 examplê.

Locality.-Ceylon (Fryer).

This species has been reported only from Ceylon.

\section{Genus Oma Spaeth.}

In discussing the scope and limits of several genera of the Cassidinæ (Archiv f. Naturg. lxxix. 1913, Abt. A. vi. p. 128), Dr. Spaeth erects the genus Oma for two species, viz., monstrosa Boh. and denticula Boh., which he separates from the genus Desmonota founded by Hope in 1839 (Ann. \& Mag. Nat. Hist. (1) iii. 1839 , p. 97$)$. The differences in the characters of Desmonota and Oma may be stated as follows :-

Desmonota Hope.-The basal six joints of the antennæ are shining, and very sparsely corered with scattered hairs. The apical five joints are opaque and thickly covered with hair. The sixth joint is much shorter than the fifth and also the following joints.

Oma Spaeth.- The basal five joints of the antennæe are shining and very sparsely covered with scattered hairs. The six apical joints are opaque, and thickly covered with hairs. The sixth joint is longer and thicker than the fifth joint and about equal in length to the following joints.

Hope took Germar's species Cassida platynota as the type of Desmonota and drew up a description of the generic characters. In doing so he was in considerable doubt, as will appear from the following extract from his remarks on the genus :- "The 
species of this division require a very accurate examination; none of my acquaintance accord altogether with the above generic characters; they require, therefore, further division; the typical insect is from the-Brazils." Boheman, the next writer on the genus who described monstrosa and denticula under Desmonota (Mon. Cassid. i. 1850, pp. 144 \& 141), evidently did not examine the specimens carefully or he would have been struck with the differences in the structure of the antennæ.

Oma denticula Boh., var. krishna, n.

The specimen before me agrees well with denticula, but the colour of the dorsal side is dark. As I cannot find any structural difference, I make this specimen the type of the new variety krishna.

Desmonota variolosa F., which is green in colour, has a similar dark variety. The occurrence of a dark variety in these allied genera is therefore not uncommon.

Locality.-South America, 25. i. 94.

It has been reported from Paraguay, Bolivia.

Type of variety in the British Museum.

Genus Prenea Spaeth.

Prenea strigata Panz.

Cassida strigata Panzer in Voet's Beschreib. u. Abb. hartsch. Ins. 1798 , p. 81 , t. 42 . f. 10.

Dolichotoma strigata Boheman, Mon. Cassid. i. 1850, p. 202.

Cassida similis Panzer, l. c. p. 81, t. 42. f. 11 ( $($ ) .

8 examples.

Locality.-A mazons (Goodman, 1879).

Range. Amazons, Ecuador.

Genus Oxynodera Hope.

OxynODERA COLLICULUS Boh.

Dolichotoma colliculus Boheman, Mon. Cassid. i. 1850, p. 189.

1 example.

Locality.-Amazons (Goodman, 1879).

It has been reported from Para.

Genus Canistra Er.

Canistra irrorata Guérin.

Oxynodera irrorata Guérin, Icon. Règne Anim., Ins. 1844, p. 289.

Canistra irrorata Boheman, Mon. Cassid. i. 1850, p. 168, t. 3. f. $c$.

2 examples.

Locality.-Amazons (Goodman, 1879).

Runge. Brazil, Misiones, Bolivia, Paraguay. 


\section{Genus Pseudomesomphalia Spaeth.}

Pseudomesomphalia chalyba Germ.

Cassida chalybae Germar, Ins. Spec. Nov. 1824, p. 532.

Mesomphalia chalyboea Boheman, Mon. Cassid. i. 1850, p. 248.

1 example.

Locality.-Brazil.

Range. Brazil, Paraguay.

Pseudomesomphalia decemguttata Sturm.

Cassida decemguttata Sturm, in Thon, Abbild. ausl. Ins. Käf. 1826-28, p. 2, t. 1. f. 3 .

Mesomphalia decemguttata Boheman, Mon. Cassid. i. 1850, p. 321 .

2 examples.

Locality.-Amazons (Goodman, 1879).

Range. Columbia, Equatorial Brazil.

Pseudomesomphalia discoides Linné.

Cassida discoides Linné, Syst. Nat. ed. 10, 1758, p. 364 ; ed. 12, 1767, i., ii. p. 578 ; ed. 13, Gmel. 1787, i., iv. p. 1642.

3 examples.

Locality.-Amazons (Goodman, 1879).

Range. Equatorial Brazil, Peru, Columbia, Venezuela, Ecuador.

This has a very wide distribution. Since the time of Linné many writers have written about it, and it has received many names. For a list of the literature and the synonyms I refer the reader to the Catalogue of Cassidinæ by Dr. Spaeth (Berlin, 1914).

\section{Genus Neomphalia Spaeth.}

Neomphalia vulnerata Boheman.

Mesomphalia vulnerata Boheman, Mon. Cassid. i. 1850, p. 249. ab. subpustulata Boh. Mon. Cassid. i. 1850, p. 250.

1 example.

Locality. - Brazil.

Neomphalia adspersa Boheman.

Mesomphalia adspersa Boheman, Mon. Cassid. i. 1850, p. 355.

2 examples.

Locality.-Amazons (Goodman, 1879).

Range. Para, Brazil.

Genus Pecilaspis Hope.

Pecilaspis pantherina Klug.

Cassida pantherina Klug, Preisverz. 1829, p. 7. 
Pocilaspis pantherina Boheman, Mon. Cassid. i. 1850, p. 413. ab. duodecimmaculata Boh. 1. c. p. 414.

5 examples.

Locality.-Pilcomayo (J. Graham Kerr).

Range. Brazil.

Pecilaspis decempustulata Boheman.

Precilaspis decempustulata Boheman, Mon. Cassid. i. 1850, p. 416 .

1 example.

Locality.-S. America, 25.i. 94.

Boheman records it from Tucuman and Rio de la Plata.

Peecilaspis nervosa F.

Cassida nervosa Fabricius, Syst. El. i. 1801, p. 405 ; Illig. Mag. Ins. v. 1806, p. 228.

Pocilaspis nervosa Boheman, Mon. Cassid. i. 1850, p. 386.

15 examples.

Locality.-Amazons (Goodman, 1879).

Range. Brazil, Paraguay.

\section{Genus Anacassis Spaeth.}

Anacassis Cribrum Klug.

Cassida cribrum Klug, Preisverz. 1829, p. 8.

Mesomphalia cribrum Boheman, Mon. Cassid. i. 1850, p. 356.

2 examples.

Locality.-Brazil.

Selenis SPINIfex Linné.

Cassida spinifex Linné, Amœn. Acad. vi. 1763, p. 392 ; Syst. Nat. ed. 12, 1767, i., ii. p. 576 ; ed. 13, Gmel. 1787, i., iv. p. 1638.

3 examples.

Locality.- South America, 25.i.94.

This is a very common insect. Many writers have written about it. I refer the reader to Spaeth's Catalogue, p. 52.

Boheman, Mon. Cassid. ii. p. 99, distinguishes $S$. nebulosa thus:-_"S. spinifex minus lata, magis convexa, prothoracis et humerorum structura, nec non elytris apice sub-rotundatis, ab illa abunde distincta." Having examined 28 examples of nebulosu and spinifex in the collection of the British Museum, I am of opinion that they must be regarded as the same species and that characters mentioned by Boheman cannot distinguish them.

Genus Еснома Spaeth.

Echoma normalis Germar.

Cassida normalis Germar, Ins. Spec. Nov. 1824, p. 538. 
Omoplata normalis Boheman, Mon. Cassid. ii. 1854, p. 104.

Cassida suturalis Olivier, Enc. méth.v. 1790, p. 385 ; Ent. vi. 1808, p. 942 ; 97 , t. 4 . f. 95 (nec F.).

2 examples.

These are without locality-labels, but it is a well-known Brazilian species.

\section{Genus Omaspides Boh.}

Omaspides clathrata L. (var. $a$ ).

1 example.

Locality.-Amazons (Goodman, 1879).

This is a common insect. It has also been reported from Dutch Guiana and Cayenne.

\section{Genus Chelymorpha Boh.}

Chelymorpha marginata L.

2 examples.

Locality.-Amazons (Goodman, 1879).

Range. Cayenne, Brazil.

Chelymorpha variolosa Oliv.

Cassida variolosa Olivier, Enc. méth. v. 1790, p. 385 ; Ent. vi. 1808, p. 9508 ; 97 , t. 2. f. 21 ; t. 3. f. 46.

1 example.

Locality.-Amazons (Goodman, 1879).

Range. Para, Cayenne.

\section{Genus Physonota Boh.}

Physonota alutacea Boh., var. cyrtodes.

Physonota alutacea Boheman, Mon. Cassicl. ii. 1854, p. 192 ; Champion, Biol. Centr.-Amer., Col. vi. (2) 1885-94 (1894), p. 166.

2 examples.

Locality.-Mexico (Gadow).

Range. Central America, Columbia, Venezuela, Mexico.

\section{Genus Batonota Hope.}

Hope erected the genus Batonota (spine-backed) in 1839 . He did not draw up any synoptical table of the allied genera. The remarkable dorsal prolongation of the elytra into a double spine led him to found this genus. He took bidens F. as the type, but at the same time he included Cassida truncata of Fabricius, which has no spine, in Batonota. Later authors did not question this inclusion of truncata F.: thus at present the genus is composed of 42 species of heterogeneous insects which obviously fall into at least three genera. Out of the 42 species 34 are 
represented in the British Museum Collection, and these I have examined. The genus Batonota may be divided as follows :-

A. Scutellum trapezoidal.

1. The elytra produced into a long dorsal double spine, the lateral sides of the elytra concave at the middle .........................................

$1^{\prime}$. The elytra not produced into a long spine, dorsally gibhous, the lateral sides of the elytra convex or straight, more explanate

Batonota Hope.

Akantaka $\dagger$, gen. nov.

$A^{\prime}$. Scutellum triangular. Insects small, ovate; elytra dorsally more or less gibbous, deeply punctate ...

Trikona + , gen. nov.

The species are distributed as follows :-

\begin{tabular}{|c|c|c|}
\hline $\begin{array}{l}\text { Genus BAтоNoтA. } \\
\text { bidens } \mathrm{F} \text {. } \\
\text { nigra Boh. } \\
\text { monoceros Germ. } \\
\text { pugionata Germ. } \\
\text { pugnax Boh. } \\
\text { cornigera Boh. } \\
\text { mucronata Boh. } \\
\text { aurita Boh. } \\
\text { parallela Blanch. } \\
\text { ensifera Boh. } \\
\text { spinosa Boh. } \\
\text { apiculata Boh. } \\
\text { aculeata Boh. } \\
\text { yucatana Champ. } \\
\text { nodosa Boh. } \\
\text { *rufomarginata Wgenr. } \\
\text { *rugosa Wgenr. } \\
\text { *minima Wgenr. } \\
\text { *bellicosa Boh. }\end{array}$ & $\begin{array}{l}\text { Genus Aкамтака. } \\
\text { funesta Boh. } \\
\text { truncata Fab. } \\
\text { peregrina Boh. } \\
\text { godmani Baly. } \\
\text { viridisignata Boh. } \\
\text { exaltata Fab. } \\
\text { dejeani Boh. } \\
\text { bivittipennis Boh. } \\
\text { rufoornata Baly. } \\
\text { kiesenvetteri Boh. } \\
\text { collaris Baly. } \\
\text { tenebrosa Boh. } \\
\text { distincta Baly. } \\
\text { sexplagiata Wgenr. } \\
\text { biplagiata Champ. } \\
\text { insidiosa Boh. } \\
\text { *kunzei Boh. } \\
\text { *marginevittata Wgenr. } \\
\text { *aneocincta Spaeth. } \\
\text { *asciata Wgenr. }\end{array}$ & $\begin{array}{l}\text { Genus TRIKona. } \\
\text { turrifera Boh. } \\
\text { humeralis Oliv. } \\
\text { lerouxi Boh. }\end{array}$ \\
\hline
\end{tabular}

In the above list I have not seen the species marked with an asterisk, but I have placed them in their respective genera with the help of Wagener's table (Mitt. Münch. Ent. Ver. v. 1881, p. 44). Batonota nodosa Boh. appears to be an intermediate form. The shape of the body is similar to some forms of Akantaka, but the double spine on the back (which is rather short) decides its position in Batonota.

Akantaka rufoornata Baly, var. amazonensis, $n$.

1 example.

I have examined six specimens of the species including the type. They are all from Nicaragua. The present example is the Brazilian variety of this species. Var. amazonensis is (1) larger, (2) the lateral sides of the elytra are more convex at the

+ Akantaka is a Sanskrit word meaning "without thorn."

+ Trikona is a Sanskrit word meaning "triangular." 
posterior angles, (3) the rufous spots on the explanate margin of the elytra are much smaller.

Locality.-Amazons (Goodman, 1879).

'Type of variety in the British Museum.

\section{Genus Aspidomorpha Hope.}

Aspidomorpha miliaris F.

Cassida miliaris Fabricius, Syst. Ent. 1775, p. 91.

Aspidomorpha miliaris Boheman, Mon. Cassid. ii. 1854, p. 261 ; Weise, Deut. Ent. Zeit. 1896, p. 16 ; Spaeth, Ann. Mus. Nat. Hung. i. 1903, p. 138 ; Maulik, Rec. Ind. Mus. ix. 1913, p. 110.

3 examples.

Locality.-Malay Penin. (Skeat Expedition, 30.xi. 1900).

Range. Philippine Is., Sunda Is., New Guinea, India, Yunnan, Tonkin.

AsPIDOMORPHA TECTA Boh.

Aspidomorpha tecta Boheman, Mon. Cassid. ii. 1854, p. 276 ;

Weise in Voeltzkow, Reise Ostafrika, Chrysomel. 1910, p. 451.

4 examples.

Locality.-S. Africa (M. Wilman).

Aspidomorpha punctum F.

Cassida punctum Fabricius, Syst. El. i. 1801, p. 404.

Aspidomorpha punctum Boheman, Mon. Cassid. ii. 1854, p. 281 ; Spaeth, Ann. Mus. Nat. Hung. i. 1903, p. 151.

1 example.

Locality.-Matador.

Range. New Guinea, Papua Is., North Australia.

It is a variable species.

Aspidomorpha inquinata Boh.

Aspidomorpha inquinata Boheman, Mon. Cassid. ii. 1854, p. 309 .

1 example.

Locality.-New Britain (A. Willey).

Hitherto it has been recorded from the Andamans and Tenasserim only. This species probably has a very wide range.

Aspidomorpha australasiæ Boisd.

Aspidomorpha australasice Boisd. Faune Ent. Océanie (Astrolabe), ii. 1835, p. 537 ; Boheman, Mon. Cassid. ii. 1854, p. 308 ; Spaeth, Ann. Mus. Nat. Hung. i. 1903, p. 147.

1 example.

Locality.-Solomon Islands (Willey).

Range. New Guinea. 
AsPIDOMORPHA ASSIMILIS Boh.

Aspidomorpha assimilis Boheman, Mon. Cassid. ii. 1854, p. 314 ; Spaeth, Ann. Mus. Civ. Genova, xli. 1904, p. 75.

1 example.

Locality.-Malay Penin. (Skeat Expedition, 30. xi. 1900).

Range. Java, Sumatra.

AsPIDOMORPHA CINCTA F.

Cassida cincta Fabricius, Spec. Ins. i. 1781, p. 109; Mant. Ins. i. 1787,p. 63 ; Ent. Syst.i. 1792, p. 295 ; Syst. El. i. 1801, p. 392 ; Linné, Syst. Nat. ed. 13, Gmel. 1787, i., iv. p. 1637 ; Herbst, Natursyst. Käf. viii. 1799, p. 331 ; Klug, Erman's Reise, 1835, p. 47.

Aspidomorpha cincta Boheman, Mon. Cassid. ii. 1854, p. 251 ; Wollaston, Col. Hesp. 1867, p. 154.

3 examples.

Localities.-Zomba, Nyasaland (Cameron, 25.iv. 1900) ; British Central Africa, 6. vi. 1908 ; Durban (F. Muir, 1902).

Aspidomorpha natalensis Boh.

Aspidomorpha natalensis Boheman, Mon. Cassid. ii. 1854, p. 303.

1 example.

Locality.-Zomba (Cameron, 25.iv. 1900).

AsPIDOMORPHA QUINQUEFASCIATA F.

Cassida quinquefasciata Fabricius, Syst. El. i. 1801, p. 401 ; Klug, Erman's Reise, 1835, p. 47.

Aspidomorpha quinquefasciata Boheman, Mon. Cassid. ii. 1854, p. 250 .

1 example.

Locality.-Nyasaland, 6. vi. 1908.

Range. Central and West Africa, Réunion.

There is very little difference between $A$. quinque-fasciata $\mathrm{F}$. and $A$. ludibunda Boh. I am inclined to think that they are the same species, particularly in view of the fact that the species of Aspidomorpha are extremely variable.

Aspidomorpha AMABILIS Boh.

Aspidomorpha amabilis Boheman, Mon. Cassid. ii. 1854, p. 315 ;

Weise, Deut. Ent. Zeit. 1897, p. 104.

Cassida micans Ol. Ent. vi. 1808, p. 960 ; 97, t. 5. f. 83 (nec F.).

Locality.-Java.

Range. India, Burma, Java, Sumatra, Ceylon.

AsPIDOMORPHA FURCATA Thunb.

Cassida furcata Thunberg, Nov. Ins. Spec. v. 1789, p. 87, t. 5 .

f. 96 ; Herbst, Natursyst. Käf. viii. 1799 , p. 265 , t. 132 . f. 7.

Proc. Zool. Soc.-1916, No. XLI. 
Cassida dorsata O1. Enc. méth. v. 1790, p. 386 ; Ent. vi. 1808, p. 961 ; 97, t. 3 . f. 45 (nec F.).

Cassida micans Fabricius, Syst. El. i. 1801, p. 398.

Aspidomorpha micans, Boh. Mon. Cassid. ii. 1854, p. 313.

1 example.

Locality.-Formosa (ex coll. G. R. Crotch),

Range. South China, India, Sunda Is.

\section{Aspidomorpha dulcicula Boh.}

Aspidomorpha dulcicula Boheman, Mon. Cassid. iv. 1862, p. 278; Spaeth, Sarawak Mus. Journ. i, 1912, p. 117 ; Maulik, Rec. Ind. Mus. ix. 1913, p. 112.

4 examples.

Locality.-Borneo (Shelfard).

Range. Sumatra, Borneo.

AsPIDOMORPHA ST, CRUCIS F.

Cassida st. crucis Fabricius, Ent. Syst. iv. 1792, App. p. 446 ; Syst. El. i. 1801, p. 401.

Aspidomorpha st. crucis Boheman, Mon. Cassid. ii. 1854, p. 287 , t. 6. f. B; Weise, Deut. Ent. Zeit. 1897, p. 102; Maulik, Rec. Ind. Mus. ix. 1913, p. 111.

5 examples.

Locality.-Java ${ }_{\text {( }} F_{\text {. Muir }}$ ), Malay Penin. (Skeat Expedition, 30. xi. 1900).

\section{Genus Canchyloctenia Spaeth.}

In his recent Catalogue of the Cassidinæ (Berlin, 1914) Dr. Spaeth has entirely omitted Boheman's species Cassida nigrovittata (Boh. Mon. Cassid. ii. 1854, p. 341). There are two examples, including the type, in the British Museum which Boheman records from Calcutta. I have seen a third example in Mr. Andrewes' collection which is from Chota Nagpur, India. The examination of these specimens reveals the fact that they cannot belong to the genus Cassida. But they agree well with the characters of Conchyloctenia as defined by Spaeth (Ann. Soc. Ent. Belg. 1902, p. 449). In the form of the body the species resembles the tigrina group; the tibire are also sulcate on the external side; nigrovittata, therefore, must come under Conchyloctenia. It is interesting to note that all the species recorded under Conchytocteria are found in Africa. This species therefore extends the distribution of the genus to the Oriental region.

CONCHYloctenia tigrina OA.

Cassida tigrina Olivier, Ent. vi. 1808, p. 957; 97, t. 5. f. 78 ; Boheman, Mon. Cassid. ii. 1854, p. 336.

2 examples.

Locality.-S. Africa (M. Wilman). 
Genus Нyвоsinota Spaeth.

Hybosinota turrigera Boh.

Cassida turrigera Boheman, Mon. Cassid. iv. 1862, p. 283.

Hybosinota turrigera Spaeth in Sjöstedt, Zool. Exped. Kilimandj. I. 1910, Abt. 7, p. 283.

Asphalisia tuta Weise, Arch. f. Naturg. lxx. 1904, i. p. 172.

1 example.

Locality._Lourenço Marques (F. Muir, 10. viii. 1900).

Runge. Zanzibar, Bechuanaland.

\section{Genus Laccoptera Boh.}

LACCOPTERA QUADRIMACUlata Thunb.

Cassida quadrimaculata Thunberg, Nov. Ins. Spec. v. 1789, p. 86, t. 5. f. 94 .

2 examples.

Locality.-Formosa (ex coll. G. R. Crotch).

Range. South China, India, Andaman Is.

\section{Genus Silana Spaeth.}

Silana farinosa Boh.

Cassida farinosa Boheman, Cat. Col. Ins. Brit. Mus. ix. 1856, p. 146 ; and Mon. Cassid. iv. 1862, p. 350.

3 examples.

Locality.-Maha Illupalama, Ceylon (J. C. F. Fryer, iii. 1912). This species has been reported from Ceylon only.

\section{Genus Cassida L.}

Cassida decipiens Spaeth.

Cassida decipiens Spaeth, Deutsche Ent. Zeitschr. 1906, p. 389 .

1 example.

Locality.-Zomba (Cameron, 25. iv. 1900).

Spaeth reports it from Mashonaland.

\section{Genus Chirida Chap.}

Chirida cruciata L.

Coptocycla cruciata Boh. Mon. Cassid. iii. 1855, p. 396.

Chirida cruciata Chapuis, Gen. Col. xi. 1875, p. 405.

1 example.

Locality.-Amazons (Goodman, 1879).

Range. Argentina, Brazil. 
Chirida scalaris Weber.

Cassida scalaris Weber, Observ. Ent. i. 1801, p. 51 ; Fabricius, Syst. El. i. 1801, p. 391 ; Olivier, Ent. vi. 1808 , p. 967 ; 97, t. 6. f. 94 .

Coptocycla scularis Boheman, Mon. Cassid. iii. 1855, p. 124.

Metriona scalaris Weise, Deutsche Ent. Zeitschr. 1897, p. 107. 2 examples.

Locality.-Malay Penin. (Skeat Expedition, 30.xi.. 1899)。

Range. India and Indo-Malay region.

Genus Thlaspida Weise.

Thlaspida Formosæ Spaeth.

Thlaspida formosce Spaeth, Ann. Mus. Nat. Hung. xi. 1913, p. 46 ; and Suppl. Ent, iii. 1914, p. 16.

1 example.

Locality.-Formosa (ex coll.G. R. Crotch).

Genus Thlaspidosoma Spaeth.

Thlaspidosoma dohrni, Spaeth.

Thlaspidosoma dohrni Spaeth, Stett. Ent. Zeit. 1xii. 1901, p. 5 ; and Sarawak Mus. Journ. i. 1912, p. 119.

4 examples.

Locality.-Borneo (Shelford, 20, x. 1901).

Range. Sumatra.

Genus Thlaspidomorpha Spaeth.

ThlaspidomorpHa BaLYi Boh.

Coptocycla balyi Boheman, Mon. Cassid, iii. 1855, pa 403.

1 example.

Locality.-Ceylon (H. H. W. Pearson).

Genus. Rңососаssis Spaeth.

Rhococassis Flavoplagiata Baly.

Coptocycla flavoplagiata Baly, Journ. Ent. ii. 1863, p. 102.

Metriona flavoplagiata Weise, Deutsche Ent. Zeitschr. 1905, p. 125.

8 examples.

Locality _-Borneo (Shelford).

Range. Sumatra, Siam.

\section{Genus Coptecycé Boh.}

Coptocycla placida (?) Boh.

Coptocycla placida Boheman, Mon. Cassid, iii. 1855, p. 415.

1 example. 
Locality.-Amazons (Goodman, 1897).

Identified from description. It has also been reported from Cayenne, Guiana.

Genus Metriona Weise.

Metriona judaica F.

Coptocycla jrudaica Boheman, Mon. Cassid. iii. 1855, p. 293 ; Champion, Biol. Centr.-Amer., Col. vi. (2) 1885-94, p. 209.

3 examples.

Locality.-Amazons (Goodman, 1879).

Range. S. America, Panama.

Metriona circumdata Herbst.

Coptocycla circumdata Boheman, Mon. Cassid. iii. 1855, p. 279. Metriona circimdata Spaeth, Ann. Mus. Nat. Hung. i. 1903, p. 128 ; Maulik, Rec. Ind. Mus. Caleutta, ix. 1913, p. 114.

1 example.

Locality.-New Britain (A. Willey, 1. iii. 1898).

Range. India, Indo-China, Philippine Is., Celebes.

\section{Genus Charidotis Boh.}

Charidotis abrupta Boh.

Charidotis abrupta Boheman, Mon. Cassid. iii. 1855, p. 11, t. 7. f. B.

15 examples.

Locality.-A mazons (Goodman, 1879).

Range. Brazil, Venezuela, Cayenne, Guiana.

\section{Genus Ctenochira Chap.}

Ctenochira gemina Boh.

Coptocycla gemina Boheman, Mon. Cassid. iii. 1855, p. 455.

1 example.

Locality.-Amazons (Goodman, 1879).

It has also been reported from Para.

Ctenochira PLeCta Ér.

Cassida plecta Erichson, Arch. f. Naturg. xiii. 1847, p. 154.

Coptocycla plecta Boheman, Mon. Cassid. iii. 1855 , p. 505.

1 example.

Locality.-A mazons (Goodman, 1879).

It has also been reported from Peru. 


\section{$2 \mathrm{BHL}$ Biodiversity Heritage Library}

Maulik, S. 1916. "28. On Cryptostome Beetles In The Cambridge University Museum Of Zoology." Proceedings of the Zoological Society of London 1916, 567-589. https://doi.org/10.1111/j.1096-3642.1916.tb02038.x.

View This Item Online: https://www.biodiversitylibrary.org/item/98501

DOI: https://doi.org/10.1111/j.1096-3642.1916.tb02038.x

Permalink: https://www.biodiversitylibrary.org/partpdf/72154

\section{Holding Institution}

Smithsonian Libraries

\section{Sponsored by}

Biodiversity Heritage Library

\section{Copyright \& Reuse}

Copyright Status: Public domain. The BHL considers that this work is no longer under copyright protection.

This document was created from content at the Biodiversity Heritage Library, the world's largest open access digital library for biodiversity literature and archives. Visit BHL at https://www.biodiversitylibrary.org. 